\title{
Masyarakat dalam Perkembangan Teknologi Informasi dan Realitas Perubahan Sosial di Era Postmodern
}

Ida Ayu Kartika Maharani ${ }^{1}$

${ }^{1}$ Institut Hindu Dharma Negeri Denpasar

\begin{abstract}
At present social changes that occur in the information revolution era, not only touch the appearance of government officials, politicians, and economic actors, but have penetrated the lifestyle and social behavior in the wider community, including the lifestyle and social behavior of young people. The existence of young people in the process of change and reform movement, is stated as one of the strengths of civil society that seems to be more easily adapted to the development of digital-based information and communication technology that is developing in digital native circles.

The development of a society that is dominated by information technology, in addition to changes in social interaction patterns and ways of communicating, there have also been changes in people's attitudes and behavior in responding to the social realities that occur around them. This reality is not merely an observable object, but has gone beyond reality itself which is called hyperreality. Hyperreality intended here is an artificial or superficial reality, created through the aid of simulation technology and imaging engineering, which takes over the natural world of reality. These are said to be models of reality, which have no reference to reality or do not have a reference or reference to reality, but only refer to themselves.

Keywords Information Technology, Social Change, Post Modernism
\end{abstract}

\section{PENDAHULUAN}

Msyarakat dunia, kini telah memasuki era post-industri, yang ditandai oleh perkembangan teknologi informasi yang demikian maju. Sugiharti dalam buku Perkembangan Masyarakat Informasi \& Teori Sosial Kontemporer (2014:37) mengutip Daniel Bells (1977) bahwa paling tidak, dapat ditelusuri dua indikasi utama dari perkembangan teknologi informasi itu. Pertama, adanya percepatan arus informasi melalui jaringan yang dipicu oleh penemuan miniature sirkuit elektronik dan serat optic. Kedua, adanya keterpaduan yang terintegrasi antara teknik computer dan telekomunikasi. Pandangan yang hampir sama dikemukakan oleh Manuel Castells, yang menyatakan bahwa era revolusi informasi ditandai dengan kemajuan teknologi informasi yang canggih.

\footnotetext{
${ }^{1}$ dayu_kartika@ihdn.ac.id
} 
Saat ini perubahan sosial yang terjadi di era revolusi informasi, tidak hanya menyentuh penampilan para penyelenggara pemerintahan, politikus, dan para pelaku ekonomi saja, melainkan telah merambah pada gaya hidup dan perilaku sosial pada masyarakat luas, termasuk gaya hidup dan perilaku sosial kaum muda. Keberadaan kaum muda dilukiskan oleh Sugiharti dalam proses perubahan dan gerakan reformasi, dinyatakannya sebagai salah satu bagian kekuatan civil society yang tampaknya lebih mudah menyesuaikan diri dengan perkembangan teknologi informasi dan komunikasi berbasis digital yang sedang berkembang di kalangan digital native.

Perilaku anak muda sebagai kaum digital native, yang terjadi di berbagai kota di Indonesia, disinyalir lebih banyak menampilkan gaya hidup santai, hedonis, acuh tak acuh, dan bersifat konsumtif, sehingga menjadi sasaran pasar bagi kekuatan industri budaya. Hal ini dikemukakannya terkait dengan keterlibatan anak-anak muda di jaringan internet dan handphone, yang melahirkan ruang publik yang semakin terbuka, bahkan cendrung tanpa batas, untuk menyalurkan aspirasi mereka baik di bidang sosial-politik maupun di bidang seni dan kenikmatan lainnya. Hal inilah yang disinyalir dapat merangsang tumbuhnya perilaku dan gaya hidup remaja urban yang lebih banyak dikendalikan oleh hasrat dan keinginan untuk membeli produk-produk industri budaya terbaru (Sugiharti, 2014:38).

Dalam hubungan ini, realitas perubahan sosial dalam perkembangan teknologi informasi dipandang menarik untuk dipresentasikan dan didiskusikan dalam seminar-seminar, seperti seminar yang sedang berlangsung saat ini.
Pembicaraan dalam kesempatan ini dibatasi pada dua topik yang saling terkait yaitu masyarakat dalam perkembangan teknologi informasi dan realitas perubahan sosial di era postmodern.

\section{PEMBAHASAN}

\section{Masyarakat Dalam Perkembangan Teknologi Informasi}

Pembahasan tentang subtopik ini, tidak dapat dilepaskan dari fenomena yang terjadi pada masyarakat dunia pada umumnya, sebagaimana telah digambarkan oleh para akhli seperti Daniel Bell, dan Manual Castells. Keduanya telah melakukan pengkajian mengenai perkembangan masyarakat informasi yang terjadi di dunia. Daniel Bells (dalam Sugiharti, 2014). mengemukakan bahwa, ada dua indikasi utama dari perkembangan teknologi informasi. Pertama, adanya percepatan arus informasi melalui jaringan yang dipicu oleh penemuan miniature sirkuit elektronik dan serat optic. Kedua, adanya keterpaduan yang terintegrasi antara teknik computer dan telekomunikasi. Sedangkan Manuel Castells (1996) dalam buku "The Rise of the Network Society Volume 1 of The Information Age: Economy, Society, and Culture, menyatakan bahwa dunia saat ini sedang memasuki era informasi, yang ditandai berbagai kemajuan teknologi informasi digital yang menyediakan berbagai bentuk jejaring organisasi dalam struktur sosial. Dewasa ini integrasi internet dalam kehidupan sosial telah menciptakan bentuk baru identitas dan ketidaksetaraan, menjadikan kekuasaan bagian dari arus desentralisasi sekaligus melahirkan bentuk-bentuk baru organisasi sosial. 
Lebih lanjut Castells (2000) dalam edisi kedua bukunya yang berjudul sama, sebagai mana dikutip oleh Ritzer \& Goodmaan, (2008:632). menyatakan bahwa telah terjadi perkembangan teknologi informasi yang demikian canggih di era revolusi informasi. Demikian juga telah berkembang satu sistem sosial budaya baru yang disebut sebagai kebudayaan virtual riil, yakni adanya setting citra maya, di dunia fantasi. Kalau sebelumnya masyarakat bergaul dalam ruang yang nyata dan bertatap muka, dengan kehadiran intermet sekarang dimungkinkan berkomunikasi dengan siapa pun, dan membentuk jejaring sosial melalui internet/computer. Hal ini tidak pernah terbayangkan terjadi sebelumnya. Keunikan teknologi informasi tidak pada kemampuannya mengakses realitas maya ke dunia nyata, melainkan kemampuannya membangun kemayaan yang nyata atau real virtuality. Dapat juga dikatakan bahwa di era postindustrial, realitas sosial telah mati, yang kemudian digantikan oleh realitasrealitas yang bersifat virtual, atau realitas cyberspace. Pokoknya serba virtual seperti kebudayaan virtual, dan komunitas virtual (Sugiharti, 2014:3940).

Pernyataan yang hampir sama dikemukakan oleh Piliang (2004:64) bahwa di zaman revolusi informasi seperti sekarang, masyarakat tidak lagi berkomunikasi dalam komunitas yang nyata, tetapi dalam komunitas virtual. Internet membentuk jaringan komunikasi dan informasi global telah memunculkan komunikasi virtual, realitas virtual, dan ruang tersendiri yang disebut cyberspace. Hal ini juga menimbulkan konsekwensi sosial yang berbeda dengan konsekwensi sosial pada dunia nyata. Borgmann menyebutnya sebagai fenomena leburnya antara fakta dan fiksi (1999:192).

Berdasarkan pendapat para akhli di atas, dapat dinyatakan bahwa dalam perkembangan masyarakat yang didominasi oleh teknologi informasi, di samping telah terjadi perubahan dalam pola interaksi sosial dan cara berkomunikasi, juga terjadi perubahan sikap dan perlaku masyarakat dalam merespon realitas sosial yang terjadi di sekitarnya. Realitas ini bukan sekedar sebagai objek yang dapat diamati, tetapi telah melampaui realitas itu sendiri yang disebut hyperrealitas. Hyperrealitas yang dimaksudkan disini adalah realitas yang bersifat artifisial atau superfisial, yang tercipta lewat bantuan teknologi simulasi dan rekayasa pencitraan, yang mengambil alih dunia realitas yang alamiah. Ini dikatakan sebagai modelmodel realitas, yang tidak ada referensinya pada realitas atau tidak memiliki rujukan atau referensi pada realitas, melainkan hanya merujuk pada dirinya sendiri.

Perubahan masyarakat yang demikian oleh Baudrillard (2006) dikatakan sebagai sebuah tren dari suatu era baru, yang didalamnya marak terjadi komunikasi bermediasi, komunikasi simbolis, dan semakin sesaknya ruang dan waktu. Menurut Turner (2012) peran media massa semakin intensif oleh konsumsi simbol-simbol. Hal ini dapat dilihat dari digunakannya merk atau cap dagang tertentu. Disini akan tampak pula tatanan sosial yang teratur berbasis pada konsumsi simbolik.

Kalau dirunut perkembangan masyarakat terdiri beberapa tahap yakni era pramodern, era postmodern, dan era post-postmodern. Kalau era pramodern 
yang lebih banyak menggunakan logika pertukaran simbolik, maka era modern bercirikan logika produksi. Sedangkan di era postmodern dan post-postmodern ditandai dengan logika simulasi.

Baudrillard (1983) menyatakan bahwa telah terjadi perubahan yang signifikan dari masyarakat modern ke masyarakat postmodern, yakni suatu perubahan yang bergerak dari pola hidup modern, yang menekankan pada aktivitas produksi dan konsumsi komoditas ke arah pola hidup postmodern, yang menitikberatkan pada simulasi dan permainan citra dan tanda dengan menggunakan kode dan model yang diatur oleh tatanan sosial baru berbasis simulasi. Saat ini dikatakannya, prinsip-prinsip modernisme sedang menghadapi kematiannya.

Selain itu, Baudrillard (1983) menyatakan, pada masyarakat postmodern sulit dibedakan mana realitas sosial yang alami dan mana realitas yang semu, dan mana pula realitas sosial yang melampaui dirinya. Di era ini apapun bisa dibuat dan direkayasa seolah-olah seperti aslinya. Segala sesuatu seolah-olah siap selalu untuk direproduksi. Dalam perkembangan ini, hiperrealitas merupakan suatu simulasi yang lebih nyata dari yang nyata, lebih cantik dari yang cantik, lebih putih dari yang putih, lebih sensual daripada seks, lebih cepat dari yang cepat, dirasakan selalu lebih menarik daripada realitas aslinya. Disini orang sulit menemukan sesuatu dari sumbernya, seperti seseorang mencari dan mendapatkan yang asli.

Karena itu, Sugiharti (2014). menggambarkan dalam rangkumannya bahwa masyarakat postmodern itu sebagai hyperrealitas. Media berhenti menjadi cerminan realitas, tetapi justru menjadi realitas itu sendiri atau bahkan lebih nyata dari realitas itu sendiri. Televisi, surat kabar, tabloid yang semakin popular sebagai contoh yang baik karena kebohongan dan distorsi yang disajikan kepada pemirsa melebihi realitas. Itulah sebabnya mengapa yang nyata (real) disubordinasikan dan bahkan dilarutkan sama sekali, sehingga sulit dibedakan dari yang nyata.

\section{Realitas Perubahan Sosial di Era Postmodern}

Realitas perubahan sosial di era postmodern ditandai oleh dominasi teknologi informasi yang melahirkan realitas semu, ruang publik di dunia maya, yang dimanfaatkan bagi digital native sebagai media untuk menyalurkan aspirasi sosial politik sehingga diperkirakan dapat mendorong perkembangan demokrasi deliberative. Dalam hubungan ini akan dikemukakan pandangan Habermas, yang mereprsentasikan diri sebagai generasi kedua Mazhab Frankrut. Menurut Turner (2003), Habermas percaya bahwa zaman modern dapat direvitalisasi dan dibangun ulang dalam landasan yang tepat bersamaan dengan piranti intelektual yang pertama kali dikembangkan selama abad ke-18.

Hardiman (2010), menyataka bahwa ruang publik menurut Habermas adalah suatu wilayah dalam kehidupan sosial yang memungkinkan setiap warga negara berbicara dan terlibat dalam berbagai silang pendapat serta secara bersama-sama membentuk pendapat umum. Kusumawidjaja \& Hamdi (2011) menguraikan hal yamh hampir sama bahwa, ruang publik disebut juga ranah khalayak pada dasarnya merupakan ruang politik tempat berlangsungnya pembahasan, perdebatan, dan 
pengambilan keputusan bersama. Melalui kehadiran ruang publik, masyarakat diharapkan dapat mengorganisasi diri untuk membangun pendapat umum, melontarkan kritik, dan bertindak sebagai watch dog sebagai bagian dari upaya masyarakat sipil yang madani untuk melakukan kontrol demokratik terhadap perilaku kelas yang berkuasa dan kelas kapitalis yang acapkali mengeksploitasi masyarakat.

Dalam pengembangan teori sosial, Sugiharti (2014) menerjemahkan pendapat Habermas bahwa, dalam upaya mengembangkan teori dan analisis tentang ruang publik telah berdialog dengan para teoritisi sosial, dan filsafat kritikal, dari berbagai aliran seperti aliran hermeneutic, Gadamer, teori sistem dan structural fungsional, ilmu sosial emperis, filsafat analitis dan linguistic, teori kognitif, serta kajian moral. Sugiharti (2014) juga menceritakan tentang Habermas mencapai premis fundamental teorinya sesudah memahami filsafat hermeneutika dan analisis bahasa Wittgenstien. Dari sini, la tahu kalau subjek-subjek manusia selalu siap untuk disatukan satu sama lain melalui upaya meraih pemahaman di dalam bahasa.

Lebih lanjut dijelaskan oleh Sugihati (2014) bahwa Habermas ketika menyusun teori tindakan komunikatif, telah berhasil memadukan berbagai teori sebagai landasan dan kerangka teori sosial dalam tradisi Marxis, Weber, dan teori kritis klasik. Namun demikian Habermas mengembangkan analisis yang berbeda dari Marx yang memfokuskan kerja sebagai hakikat manusia. Habermas membedakan pengertian kerja dan interaki sosial. Disini la sering menggunakan istilah tindakan komunikatif ketika seseorang mengembangkan hubungan-hubungan sosial untuk mencapai kesepakatan bersama dengan syarat bahwa orangorang itu telah sepakat dengan rencana tindakan mereka bersama untuk merealisasikan tujuan bersama yang telah disepakati itu. Dengan kata lain, tindakan komunikatif dilakukan untuk mencapai pemahaman komunikatif. Habermas berpendirian, tindakan komunikatif adalah dasar bagi berlangsungnya seluruh aktivitas sosial budaya.

Masih dalam wacana proses komunikasi dalam ruang publik, Habermas berpendapat bahwa komunikasi itu idealnya dilakukan dalam kondisi komunikasi yang bebas distorsi, tidak ada manipulasi, pemaksaan dan dominasi, yang menimbulkan situasi komunikasi yang tidak seimbang dan tidak lancar. Namun pada kenyataannya, hampir tidak ditemukan kondisi yang demikian. Pada banyak kasus, sering terjadi para penguasa ingin mempertahankan status quo, atau ketika kekuatan kapitalis ingin menguasai selera pasar, disinilah sering terjadi pemaksaan, dominasi, dan distorsi secara massif.

Dalam situasi komunikasi seperti ini akan sulit diharapkan peran kawula muda sebagai bagian dari digital native untuk menyalurkan aspirasi sosial politik mereka di ruang publik. Dalam hubungan ini, benar apa yang ditulis oleh Armando (Prisma Vol.30.2, 2011: 90-91), yang menyatakan, kehadiran media massa sebagai pilar demokrasi keempat seharusnya menjadi instrument untuk membuka wawasan anak-anak muda dari hegemoni informasi yang tunggal, seperti yang pernah terjadi di era Soeharto dahulu. Kemudian di era pasca reformasi, apakah harapan terhadap 
peran media massa, dapat mendorong sikap kritis makin meningkat dan kawula muda sebagai motor penggerak civil society mampu berperan sebagai kontrol sosial terhadap penguasa ?. Ternyata media massa di Indonesia justru dikendalikan dan dioperasikan sebagai entitas bisnis yang berorientasi pada keuntungan dan penumpukan modal semata. Maka yang terjadi kemudian adalah media massa justru berfungsi sebagai kekuatan anti demokrasi, jauh dari harapan sebagai penyangga perkembangan demokrasi.

Pernyataan yang hampir sama dikemukakan oleh Theodor W. Adorno (dalam Babe, 2009:18-32), media massa di era post-industri beroperasi berdasarkan logika industry yang kapitalistik, yakni barang dan jasa diproduksi merespon kebutuhan pasar untuk memperoleh keuntungan dan penumpukan modal. Disini peran media massa yang seharusnya menjadi sarana penyalur aspirasi sosial-politik masyarakat dimanfaatkan semaksimal mungkin untuk mengegemoni publik. Hal ini tampak dengan jelas pada perkembangan bisnis media massa berbasis kapitalis yang menekankan pada upaya mendapatkan keuntungan semata. Media massa di era post industri belum mampu berperan banyak untuk membuka pintu tumbuhnya pemikiran kritis masyarakat, bahkan sebaliknya menjadi sarana melakukan hegemoni bagi kelompok yang berkuasa. Akibatnya cara berpikir masyarakat menjadi apatis terhadap berbagai informasi publik.

\section{Ruang Publik: Prasyarat Yang Dibutuhkan}

Ruang public yang terkait dengan masyarakat post-industri adalah ruang komunikasi di dunia maya atau
Wattimena (tanpa tahun) menyebutnya sebagai agora electronic yakni ruang dalam cyberspace untuk menyampaikan apapun aspirasi sosial politik. Dalam ruang public seperti ini kaum muda termasuk digital natives memperoleh peluang mengembangkan agora electronic sebagai wahana pesemaian demokrasi delebratif atau arena beraktualisasi diri sebagai bagian dari civil society yang sangat terbuka. Walaupun disadari bahwa hal ini tidak mudah tanpa didukung kesadaran dan pendidikan politik yang mampu membongkar hegemoni yang membelenggu digital natives selama ini.

Untuk itu menurut Youniss \& Levine (2009) tidak hanya dilakukan sejak dini melalui kurikulum pendidikan dalam proses pengembangan demokrasi, melainkan yang penting adalah menumbuhkan kesadaran sebagaian dari warga negara yang memiliki tanggung jawab untuk melakukan hal-hal yang lebih besar daripada sekedar melakukan aktivitas yang menyenangkan dan konsumtif semata.

\section{PENUTUP}

\section{Simpulan}

Bedasarkan pembahasan di atas dapat disimpulkan hal-hal sebagai berikut:

Dalam perkembangan masyarakat yang didominasi oleh teknologi informasi, di samping telah terjadi perubahan dalam pola interaksi sosial dan cara berkomunikasi, juga terjadi perubahan sikap dan perlaku masyarakat dalam merespon realitas sosial yang terjadi di sekitarnya. Realitas ini bukan sekedar sebagai objek yang dapat diamati, tetapi telah melampaui realitas itu sendiri yang disebut hyperrealitas. 
Realitas perubahan sosial di era postmodern ditandai oleh dominasi teknologi informasi yang melahirkan realitas semu, ruang publik di dunia maya, yang dimanfaatkan bagi digital native sebagai media untuk menyalurkan aspirasi sosial politik sehingga diperkirakan dapat mendorong perkembangan demokrasi deliberative.

Peran media massa yang seharusnya menjadi sarana penyalur aspirasi sosial-politik masyarakat dimanfaatkan semaksimal mungkin untuk mengegemoni publik. $\mathrm{Hal}$ ini tampak dengan jelas pada perkembangan bisnis media massa berbasis kapitalis yang menekankan pada upaya mendapatkan keuntungan semata. Media massa di era post industry belum mampu berperan banyak untuk membuka pintu tumbuhnya pemikiran kritis masyarakat, bahkan sebaliknya menjadi sarana melakukan hegemoni bagi kelompok yang berkuasa. Akibatnya cara berpikir masyarakat menjadi apatis terhadap berbagai informasi publik.

Ruang public dibutuhkan sebagai prasyarat oleh kaum muda termasuk digital natives untuk mengembangkan agora electronic sebagai wahana pesemaian demokrasi delebratif atau arena beraktualisasi diri sebagai bagian dari civil society yang sangat terbuka. Walaupun disadari bahwa hal ini tidak mudah tanpa didukung kesadaran dan pendidikan politik yang mampu membongkar hegemoni yang membelenggu digital natives selama ini.

\section{DAFTAR PUSTAKA}

Armando, Ade. 2011. Media Baru Bagi Kaum Digital Natives: Demokrasi atau Kesia-siaan?" dalam Prisma Vol. 30 No.2
Baudrillard, Jean P. 2006. Masyarakat Konsumsi. Cetakan Kedua. Yogyakarta: Kreasi Wacana.

Babe, Robert E. 2009. Cultural Studies and Political Economy: Toward a New Integration. Plymouth: Lexington Books.

Castells, manuel.2000. The Rise Network Society Secound Edition.USA,UKAusralia: Blackwell Publishing.

Hardiman, F.Budi.2009. Demokrasi Delibratif, Menimbang Negara Hukum dan Ruang Publik dalam Teori Diskursus Jurgen Habermas.Yogyakarta: Kanisius

Hardiman.F.Budi.2010.Ruang Publik, Melacak Partisipasi Demokratis dari Polis Sampai Cyberspace. Yogyakarta: Kanisius.

Kusumawijaya, Marco \& Mujtaba Hamdi.2011. "Merawat Khalayak dan Ruang Khalayak" dalam Prisma Vol.30.No.1 2011.

Sugiharti, Rahma. 2014.Perkembangan Masyarakat Informasi \& Teori Sosial Kontemporer. Jakarta: Kencana Prenadamedia Group.

Turner, Bryan.2008.Teori-Teori Sosiologi Modernitas Postmodernitas. Yogyakarta: Pustaka Pelajar.

Wattimena, Reza Antonius Alexander, tanpa tahun. Menggagas Cyberspace Sebagai Ruang Publik Virtual yang Emansipatif, sebuah Analisis Cultural Studies atas 
Ambiguitas Pola Komunikasi dan Identitas di Dalam cyberspace, dalam Sutrino, In Bene \& Hendar Putranto (eds.), tanpa tahun. Cultural Studies Tantangan Bagi Teori-Teori

Besar

Kebudaaan.Depok:Koeloesan

Youniss, James \& Peter Levine (Eds.).2009. Engang Young People in Civic Life. Nashville: Vanderbilt University Press 